\title{
A HISTORY OF MARINE FISHERIES SCIENCE IN ATLANTIC CANADA AND ITS ROLE IN THE MANAGEMENT OF FISHERIES
}

\author{
R. G. HALLIDAY * AND L. P. FANNING ** \\ Population Ecology Division, Science Branch \\ Department of Fisheries and Oceans, Maritimes Region \\ Bedford Institute of Oceanography \\ PO Box 1006 \\ Dartmouth, Nova Scotia B2Y $4 A 2$
}

\begin{abstract}
The roots of fisheries science on the Atlantic coast of Canada go back to 1898 . The primary research agencies were the Fisheries Research Board of Canada and predecessors until the early 1970 s and subsequently the federal department responsible for fisheries. Canadian research on Atlantic fisheries expanded substantially after the Second World War, at about the time the International Commission for the Northwest Atlantic Fisheries was formed, and increased again after the 1977 extension of fisheries jurisdiction, but gradually declined from the 1980s. Initially research was directed at improving and expanding the fisheries through exploring for new resources and by introducing and testing new fishing methods and new processing technologies, but increasingly was directed towards rational exploitation of the fisheries as international fishing effort greatly expanded in the 1960s. By the 1980s, the provision of short-term advice on catch limits occupied a large proportion of science resources. This paper describes these changes with primary reference to groundfish fisheries, which were the most important for much of the period.
\end{abstract}

Les racines des sciences halieutiques sur la côte atlantique du Canada remontent à 1898. Jusqu'au début des années 1970 , les principaux organismes de recherche étaient le Conseil de recherche sur les pêcheries du Canada et ses prédécesseurs. Par la suite, le ministère fédéral responsable des pêches a assumé ce rôle. La recherche menée au Canada sur les pêches dans l'Atlantique a pris beaucoup d'ampleur après la Seconde Guerre mondiale, à peu près au moment où la Commission internationale pour les pêcheries de l'Atlantique Nord-Ouest a été créée, et également après l'élargissement du champ de compétence du Canada en matière de pêche en 1977, mais elle est en période de déclin graduel depuis les années 1980. Au début, la recherche était axée sur l'amélioration et l'expansion des pêches par le biais de l'étude de nouvelles ressources et de l'élaboration et de l'essai de nouvelles méthodes de pêche et technologies de transformation. Au fil du temps, le point de mire de la recherche est devenu l'exploitation rationnelle des ressources halieutiques, étant donné l'important accroissement de l'effort de pêche sur la scène internationale dans les années 1960. Dans les années 1980, une bonne part des ressources scientifiques étaient occupées à fournir des conseils à court terme à propos des limites de prises. Le présent document décrit ces changements en mettant l'accent sur les pêches de poissons de fond, qui étaient les activités les plus importantes pour la majeure partie de cette période.

* Author to whom correspondence should be addressed

E-mail: hallidayr@mar.dfo-mpo.gc.ca

** Present address: Project Manager, Lesser Antilles Pelagic Ecosystem Project, FAO Subregional Office for the Caribbean, PO Box 631-C, Bridgetown, Barbados 


\section{INTRODUCTION}

This paper provides a brief description of the development of fisheries science in Atlantic Canada in the context of the evolution of the marine fisheries and their management in the Northwest Atlantic. Emphasis is placed on groundfish (benthic species such as Atlantic cod, haddock, redfish and flatfish) as historically they have been of most importance to the fishery, even if no longer so. The foundations of modern fisheries science were laid in the first half of the 20th century (Smith 1994) but the focus of this paper is primarily on the period from 1950, i.e. from the time when international institutions were put in place to apply fisheries science broadly to North Atlantic fisheries (Halliday \& Pinhorn 1996). References to 'management' in accounts of the fisheries prior to this date relate almost exclusively to maintenance of order on the fishing grounds and to the over-riding question of "who gets the fish?" (Gough 1991, 1993).

Fisheries science is science that is conducted in support of the management of fisheries. Its central element is biological research on the factors controlling the production of aquatic species of possible or established commercial importance and estimation of their yield potential. However, it is usually viewed more broadly to include monitoring of fishing activities, of fish populations and of the environment, and research on fishing gears and practices and on the effects of fishing on the environment. It includes also research on the economic and social aspects of the fishing industry, and technological and product research and development.

In contrast, fisheries management is the administration of fishing-related activities to provide whatever societal benefits that the management authority considers worthwhile. A pre-condition to managerial success is preventing fishing from reducing the productive capacity of the resource. Thus, the key role of science is to define the biological bounds within which the social and economic benefits from fishing can be pursued. However, science has also been used to define 'optimal' exploitation strategies in terms of tonnage caught, catch per unit of fishing effort, and size or condition of the fish caught.

The success of fisheries science depends not only on the amount of new knowledge and information it generates, but also on how effectively this knowledge is communicated to fisheries managers and to the fishing industry. Thus, the institutional arrangements for the transformation of knowledge into practical advice are described also. It is equally the case, however, that the science contribution to management is devalued if it is not properly utilized or if the management authority does not establish effective control of fishing activities. Thus, institutional arrangements for management also have a place in this review. 


\section{THE FISHERIES}

There are a number of descriptions of the marine fisheries in the Northwest Atlantic from their beginning in the early 1500 s to the present day, the most recent being that by Lear (1998). By the early 1900s, the fishing banks off Canada's coast were exploited by local fleets from Canada, Newfoundland and the United States, and by the salt-cod fleets of France and Portugal. However, the introduction of the factory-equipped freezer stern trawler in 1954 revolutionized the fishery in the Northwest Atlantic, and throughout the world. These vessels combined the concepts of stern trawling with on-board filleting machinery, freezing capability and a fish-meal reduction plant and thus removed the constraint placed on distant-water fishing by the limited time fish can be preserved on ice. Development of one-boat mid-water trawling in the late 1960s rounded out the capabilities of the factory trawler by greatly increasing its efficiency to catch pelagic species such as herring, mackerel, and capelin. These and other technological improvements that became widely available after the Second World War, such as synthetic twines, sonic fish location systems (echo sounder, Sonar) and radio-based navigational systems (Decca, Loran, Radar), opened the way for development of diversified high-volume fisheries and a consequent doubling of Northwest Atlantic catches in the 1960s.

The new, factory-trawler equipped, distant-water fleets that appeared in the Northwest Atlantic in the late 1950s initially competed directly with traditional participants in fisheries for cod, redfish, haddock, and flatfish, but also developed fisheries for new species. Particularly significant was the expansion of small-mesh gear fisheries, spearheaded by the Union of Soviet Socialist Republics (USSR) in the early 1960s, predominantly for red and silver hakes in the southern part of the area. The USSR also pioneered development of offshore Atlantic herring fisheries in the 1960s that, combined with Canadian development of large coastal herring fisheries to support a fish-meal industry, gave herring an increased prominence in Northwest Atlantic fisheries. Groundfish catches declined from the mid-1960s, but pelagic species catches increased, first for herring, then mackerel and capelin, so that catches overall were maintained until the mid 1970s. Invertebrate fisheries also assumed more importance through the 1970s, squids being of primary importance in an international fishery context. Despite these continuing diversions to new species, total catches reported from the Northwest Atlantic peaked in 1968 at 4.5 million tons (Fig 1). There was a subsequent decline in removals in the 1970 s, followed by a period of stability in the 1980 s at about 3.0 million tons and then a further decline in the early 1990s. Late 1990s removals were about 2.0 million tons, about the same as in the mid 1950s. Species composition was quite different, however, cod representing $50 \%$ of the catches in the mid 1950 s, but only about $2 \%$ in the late 1990 s (Fig 2). It was invertebrate species, lobster, scallop, shrimp, crab, etc., that represented $50 \%$ of the catch in the late 1990s (in terms of weight, and a substantially higher percentage in terms of value). 


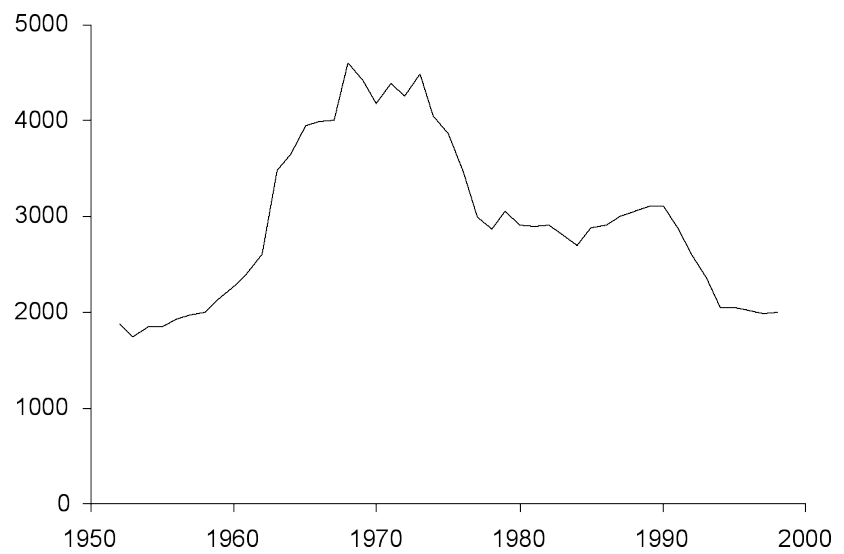

Fig 1 Reported catches from the Northwest Atlantic (all waters) in thousands of metric tons.

Mid-1950s

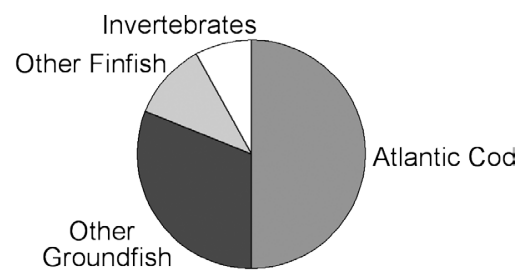

Late-1990s

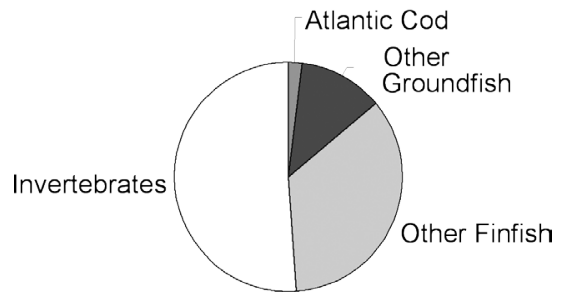

Fig 2 Proportion of catches from the Northwest Atlantic (all waters) by species group, late 1990s compared to mid-1950s.

\section{FISHERIES MANAGEMENT}

Until the late 1970s, fisheries were prosecuted, in large part, on the high seas and regulatory actions required international agreement. It was to this end that the International Commission for the Northwest Atlantic Fisheries (ICNAF) was established in 1950 "for the investigation, protection and conservation of the fisheries". Discussions at the Third United Nations Conference on the Law of the Sea reached a stage by 1976 that countries felt they were in a position to declare 200-mile fisheries zones. Canada extended its jurisdiction over most of the fishing banks off its coast (Fig 3 ) at the beginning of 1977. (Neighbouring states also extended their jurisdictions at about the same time.) However, important fishing areas on the eastern 


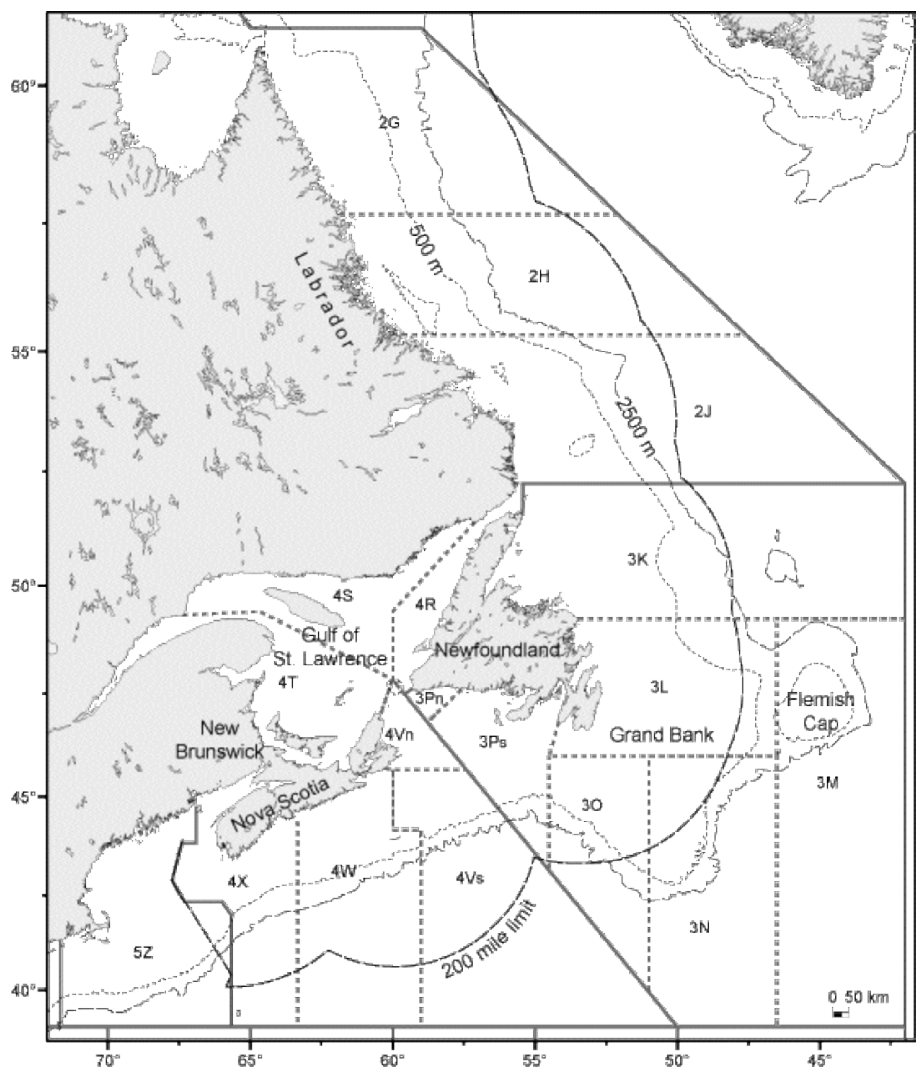

Fig 3 The Canadian fishing zone and the NAFO statistical divisions in Subareas 2-4.

and southern parts (nose and tail) of the Grand Bank, and on Flemish Cap, lay outside the new limits and thus there was a need for continuation of arrangements for international fisheries management in these areas. Anew international convention came into effect in 1979, creating the Northwest Atlantic Fisheries Organization (NAFO), to meet this need.

A detailed account of the objectives, strategies and regulatory actions adopted by Northwest Atlantic management agencies, international and national, are provided by Anderson (1998), Halliday and Pinhorn (1996) and Parsons (1993a). The latter two publications provide comparisons among management programs on both sides of the Atlantic. Briefly, the objective of ICNAF was to prevent over-exploitation, by limiting fishing to the amount that provided for the maximum sustainable catch (yield) (MSY). However, MSY is an abstract concept not well suited to practical application (Gulland 1968, Larkin 1977), and ICNAF used as a proxy the maximum yield per recruit (see below). The primary strategies were to control a) the size at which fish were first captured by regulating the characteristics of fishing gears, particularly the mesh size in otter trawls, and b) the overall 
mortality on those fish large enough to be caught, mainly by setting limits on the total allowable catch (TAC) that could be taken from each fish stock. The fishing mortality measure most commonly used is the instantaneous rate, designated by $\mathrm{F}$, which theoretically is proportional to fishing effort, and that associated with maximum yield per recruit is referred to as $F_{\max }$. Although ICNAF modified its objective to "optimal utilization" in 1971, $F_{\text {max }}$ continued to be used as its target reference point. Nonetheless, ICNAF was a leader among international commissions in establishing catch limits for individual stocks in 1970 and in subsequently adopting second-tier constraints on catch (ICNAF 1974, O'Boyle 1985) and fishing effort (ICNAF 1976) to address fishery and species interactions and the limitations of the first-tier TAC system.

After extension of jurisdiction, Canada adopted an objective of "best use" to be defined in terms of net social benefits (DOE [Department of Environment] 1976). This was to be achieved by fishing at a low fishing mortality rate, $F_{0.1}$ (an $F$ that gives a catch almost as high as fishing at $F_{\text {max }}$ but at about two thirds of the fishing effort - for a technical definition see Gulland \& Boerema (1973)). Canada had been successful in convincing ICNAF, in its dying days, to conform to this low $F$ strategy. This consensus carried over into NAFO (which retained ICNAF's objective of optimal utilization) but broke down in the mid 1980s as the European Union, struggling to accommodate the fishing interests of its new members, Spain and Portugal, came to see $\mathrm{F}_{\max }$ as the preferable reference point for NAFO management.

In Canada, legislative authority for fisheries lies with the federal government, which administers marine fisheries through its Department of Fisheries and Oceans (DFO) ${ }^{1}$. The bureaucracy in DFO, after consultations with scientific and fishing industry advisors, provides recommendations on policies, plans and regulations to the Minister, who carries the overall decision-making authority. Exceptionally, from 1993, an independent Fisheries Resource Conservation Council (FRCC) has provided recommendations directly to the Minister on conservation measures for groundfish stocks.

The Canadian fisheries bureaucracy is highly regionalized. On the Atlantic coast, there are Newfoundland, Laurentian and Maritimes regions, the last having two sectors the Gulf (southwestern part of the Gulf of St. Lawrence) and Scotia-Fundy. Each has administrative branches for managing the fisheries within their region, including policy, planning, licensing, surveillance and enforcement functions (referred to as operational branches or, collectively, as 'operations'), and a science branch. Most of the fisheries science conducted in Newfoundland Region pertains to fisheries in NAFO Subareas 2 and 3 (Fig 3), in Laurentian Region in Divisions 4RS and T (in part), Gulf Sector in Division 4T (in part) and Scotia-Fundy Sector in Divisions 4VWX and Subarea 5, but responsibilities for highly migratory species are assigned to particular laboratories on a practical basis.

The name of the federal department responsible for fisheries has changed a number of times over the years and a generic designation as the 'fisheries department' is used in the remainder of the text to avoid confusion. 
Canada's extension of jurisdiction in 1977 required the introduction of annual management plans, initially for groundfish, to establish TACs, allocate fishing opportunities between offshore and inshore fleets and to stretch out the resources to keep the industry operating year-round. Limited entry licensing and vessel replacement restrictions, intended to balance fleet catching capacity with resource availability, were introduced at this time. However, these measures proved ineffective and fleets expanded, causing demands for more fish and widespread underreporting and misreporting of catches (Halliday et al. 1992, Parsons 1993a). Management plans became progressively more complex as managers attempted to reconcile the catch aspirations of rival groups within inshore and offshore components with TAC limits. Development of fleet over-capacity is the classic consequence of fishing under a common property system because, under this system, fishermen see themselves as being in a race for the fish and are motivated to invest in ever bigger boats to compete (Gordon 1954). By the late 1970s, economists began to propose giving quantitative (property) rights to fishing entities (individual fishermen, fishing enterprises or communities) as a way to solve this problem. They argued that if fishermen were assured of being able to catch a certain amount of fish, they would no longer be motivated to increase their catching capacity. The effectiveness of this tool depends on many aspects of its application, particularly on the extent to which the rights are true property rights that can be freely bought and sold and, as for all catch limitation schemes, on the probability of violations being detected (Copes 1986). Reservations about the introduction of property rights are primarily about the potential for adverse social effects on individual fishermen and on coastal communities when the distribution of benefits from the fishery is at the mercy of market forces (Copes 1997). The introduction of such property rights to Atlantic coast fisheries began with the Bay of Fundy herring purse seine fishery in 1976 and in the offshore groundfish fishery from 1982 (Parsons 1993a) and subsequently to various other fisheries as the need arose.

For many years, the approach to management was fragmented; management plans were essentially catch sharing arrangements while regulations and policies were promulgated separately and insufficient attention was paid to measuring their effects. As a result, objectives were not being met (e.g., Angel et al. 1994). The introduction of "integrated" planning in 1995, which required inclusion of a statement of objectives and criteria for performance evaluation in management plans, was recognition of the need for a more focussed, cohesive approach. A major revision of the process begun in 2000 , labelled the Objective-Based Fisheries Management (OBFM) planning initiative, addressed a number of outstanding weaknesses in implementation by adding a requirement for rigorous risk analyses and introduced the precautionary approach (FAO, 1995). Introduction of this comprehensive framework for the management of individual fisheries coincided with the promulgation of a new fisheries policy (DFO 2004), the first comprehensive 
statement of policy since 1976 (DOE 1976) $)^{2}$. The objective of this new policy, in addition to conservation, is a self-reliant industry achieved through shared stewardship with stability and transparency in access and allocation. The value of the new policy and planning procedures is, of course, contingent on them being successfully implemented. An unacknowledged objective of governments to sustain coastal communities by providing capital and income subsidies to the fishing industry has undermined the success of past rationalization efforts (Schrank 2005).

\section{SCIENCE ADVISORY AGENCIES}

Concern about the effects of fishing on fish stocks was a primary motivation of the European scientists who established the International Council for the Exploration of the Sea (ICES) in 1902 (Went 1972), and this organization became the scientific advisory agency for the Northeast Atlantic fisheries commissions and for its member states. The governments of Canada, Newfoundland and the USA decided to form their own fishery science organization for the western North Atlantic, the North American Council on Fishery Investigations, in 1920 and were subsequently joined by France (NACFI 1932). NACFI became defunct with the outbreak of the Second World War and the fathers of ICNAF decided that the organization itself would coordinate the work of the research agencies of member states to ensure it received appropriate scientific advice. It established a Standing Committee on Research and Statistics (STACRES), composed of scientists from member countries, which provided critical peer review of scientific analyses and developed advice by consensus. The subsequent NAFO convention established a Scientific Council that operated on similar principles.

Prior to its 1977 extension of jurisdiction, Canada dealt with domestic fishery management issues as crises occurred and no mechanisms existed for the application of science to management on an ongoing basis. After jurisdictional extension, Canada could not continue to deal with its greatly expanded responsibilities on the same ad hoc basis as before. A domestic scientific advisory organization was created by the federal fisheries department in 1977, the Canadian Atlantic Fisheries Scientific Advisory Committee (CAFSAC). It was modelled on the STACRES of ICNAF, subcommittees providing technical review of scientific analyses and a steering committee providing co-ordination and policy guidance. CAFSAC was disbanded at the end of 1992 and its advisory role for groundfish was given to the new FRCC in 1993. The FRCC was composed of members of the fishing industry and non-government scientists. It was still the responsibility of DFO scientists to do the actual groundfish stock assessments and provide suites of regulatory

2 Although a new policy for Atlantic fisheries (Kirby 1983), put forward in 1982, provided a blueprint for subsequent government actions to address economic and social problems in the industry (Parsons 1993b), it did not address conservation issues. 
options for the FRCC to choose among, so the need for scientific peer review remained. Furthermore, CAFSAC had provided advice for all stocks, not just groundfish, and its demise eliminated the review mechanism for pelagic, invertebrate, marine mammal and freshwater fish stock assessments as well. Regional science branches initially established ad hoc arrangements for peer review of assessments that subsequently became formalized as a new Regional Advisory Process (RAP). The role of RAP broadened over time to one of advising on all marine conservation issues.

\section{FISHERIES RESEARCH INSTITUTIONS, STAFF AND FACILITIES}

The federal government has been responsible for almost all of the fisheries research conducted in Atlantic Canada. The organization of fundamental importance in shaping the history of research on fish and fisheries was the Fisheries Research Board of Canada (FRB) established in 1937. (For a history of the FRB and its predecessors, the Biological Board of Canada established in 1912 and the Board of Management created in 1898 see Johnstone (1977)). The FRB inherited Atlantic coast facilities that included a biological research laboratory in St Andrews, New Brunswick, originally established in 1908, and a laboratory in Halifax, Nova Scotia, that had been established in 1925 to conduct scientific research to improve the handling, processing and quality of fish products (for a history of the technological program, see Stewart \& Safer (2005)). With Newfoundland's entry into confederation with Canada in 1949, its government laboratory that in various forms had been responsible for fisheries research in Newfoundland from 1931 was taken over by the FRB. In the early 1960s, the Bedford Institute of Oceanography, which included a new FRB laboratory for the study of marine ecology, was established in Dartmouth, Nova Scotia, and provided a major expansion in marine science on the Atlantic coast. The FRB laboratories were removed from Board control in 1973 and those involved in fisheries research were subsequently integrated into the regional fisheries administrations. These regional administrations had been developing their own applied research capabilities in the form of Resource Development branches and these were amalgamated with the fisheries research components of FRB to create new regional fisheries science branches. In general, the provinces have not engaged in marine fisheries research. The province of Quebec, however, has supported limited research on marine species as a result of the unique situation where some federal responsibilities for marine fisheries were delegated to it. University researchers played important roles in the initial establishment of Atlantic coast fisheries laboratories. From the 1990s, their role increased as the federal government provided financial encouragement for universities to take on aspects of the research that was within the mandate of federal laboratories. However, overall, universities have played only a minor role in fisheries research.

The numbers of professional scientific staff in Atlantic coast FRB laboratories were low in the early years, e.g. less than 10 at the Biological Station 
in St. Andrews prior to the Second World War (Hart 1958). However, postwar, there was a substantial expansion (to 24 at the St. Andrews Station by 1954 (Hart 1958)). Needler (1984) attributed this to a positive change in public attitude towards research, resulting in greater demand at a time when government had more spending flexibility. The next big expansion in fisheries research occurred in the late 1970s when staff working on marine finfish doubled in support of the new responsibilities that came with extended fisheries jurisdiction, a need emphasized by a collapse of the groundfish stocks in the early 1970s. A gradual attrition followed from the mid 1980s to the present as research budgets were reduced and other priorities emerged.

The FRB did not pursue research on fishery economics, nor was such research included in the mandate of the Science branches subsequent to the early 1970s amalgamation with the fisheries department. Departmental economists resided within the operational part of the organization (primarily in Ottawa) and were largely involved in policy development rather than research. Although the comprehensive fisheries policy document produced in 1976 (DOE 1976) emphasized the importance of economic and social factors in achieving "best use" of fisheries resources, only a few new economics staff were hired, in contrast to the large increase in biological research (Parsons 1993a).

Vessels dedicated to research, and equipped with specialized gear and instrumentation, are essential for scientific research at sea. Commercial fishing boats sometimes can serve as satisfactory scientific observational platforms and in some specific cases are preferable but, for many tasks, they are not suitable. Prior to 1958, the largest vessels operated by the FRB Atlantic coast stations were only about $25 \mathrm{~m}$ long. These vessels were operated offshore at times, but their lack of facilities and seaworthiness was a severe limitation. The A. T. Cameron, a $54 \mathrm{~m}$ steel side trawler designed for research purposes, commissioned in 1958, was the first truly offshore Canadian Atlantic coast fisheries research vessel. A $40 \mathrm{~m}$ steel stern trawler, the E. E. Prince, was added to the fleet in 1966 but this vessel was designed for operation only in coastal and southern waters. The inadequacy of this research fleet was highlighted in preparations for the 1977 extension of jurisdiction. Two fishing trawlers converted for research purposes, the Gadus Atlantica and the Lady Hammond, were acquired immediately under long-term charters and a building program was initiated which resulted in the commissioning of two new research trawlers, the Wilfred Templeman in 1981 (which replaced the A. T. Cameron) and the Alfred Needler in 1982. These vessels were in the 50-80 m length range. The fleet was reduced in the early 1990 s with decommissioning of the E. E. Prince and termination of the Lady Hammond charter. Of the three offshore vessels remaining in 2005, the Alfred Needler, Wilfred Templeman and Teleost (chartered to replace the Gadus Atlantica in 1995), one is scheduled for retirement. 


\section{FISHERIES RESEARCH}

\section{Prior to 1950}

The effects of fishing on fish stocks was an active research topic in the early years of the $20^{\text {th }}$ century and the modern theory of fishing was elaborated in the 1930s (Graham 1935). This theory stated that there was an exploitation rate that maximized the growth potential of a stock and that fishing beyond this level resulted in no further increase, or in a decrease, in yield. A corollary to this theory was that yield was a function also of the age at which fish were first caught. Yield would increase with increasing age at first capture as long as population increase due to growth exceeded loss due to natural mortality.

Research in Atlantic Canada was influenced by the early thinking that led to the theory of fishing and work was directed toward obtaining the information needed to understand the dynamics of populations. In the earliest years, work at the St. Andrews laboratory was by volunteer investigators from the universities and was broadly exploratory emphasizing studies of the fauna and flora and their life-histories. However, by the 1920s, the need for more concentration on practical fisheries problems led to the hiring of full-time staff, and research effort focussed on resources of commercial importance and to the development of fishing gears. Examples of work of practical importance to marine fisheries include (from Hart (1958) unless referenced otherwise):

- the Canadian Fisheries Expedition in 1914-15 led by Johann Hjort that explored the biology of herring in relation to oceanographic conditions

- the comprehensive description of the interrelationships of haddock stocks in the late 1920s (Needler 1930)

- the early 1930s study of the effects of tidal power projects on the Bay of Fundy herring fisheries

- the description of the biology of cod and haddock in the Newfoundland area (Thompson 1939, 1943)

- the early 1940s promotion of new groundfish fishing methods to increase fishing efficiency.

According to its Annual Report for 1950, the work of the St. Andrews Biological Station was "to provide, through research, the basis for maintaining and increasing the supplies of raw materials for the fishing industry and for making them more available by improving catching methods" (Needler 1950). This was to be done by "exploration for new resources, discovery of the basis for regulating intensive fisheries to assure the maximum longterm yield, improvement of methods of increasing production by positive cultivation, and developing and testing of more effective means of finding and catching fish". 


\section{0 to 1990}

The yield-per-recruit theory of Beverton and Holt (1957) and the methodologies they elaborated allowed the quantification of yield expected from a particular fish stock corresponding to any level of overall fishing mortality and age at first capture. This was just the set of tools scientists' needed to apply the theory of fishing. It provided a basis for giving quantitative advice on regulatory requirements to the new international fisheries commissions. Yield-per-recruit modelling of fish population dynamics became the predominant methodology for determining the status of fish stocks.

The post-war staff increases allowed the greatly expanded data collection on the commercial fisheries that was necessary for the application of these new scientific methods. A program was initiated to sample the sizes and ages of fish in commercial landings using samplers in the main ports, and a fishermen's logbook system was established that recorded the area in which fish were caught (rather than port of landing) and the amount of fishing effort expended to make the catch. These long-term monitoring programs continue today, although the logbook system was taken over by the operations side, which was already responsible for landings statistics, in the late 1970s. Research was intensified on stock structure and on the biological parameters of stocks such as their growth, sexual maturation and mortality rates.

The first issue on the ICNAF agenda was to reduce the wastage of fish at sea that resulted from the discarding by otter trawlers, the predominant gear used, of those fish that were too small to market. Although it was known that the size of the meshes in the netting in the codend part of the trawl influenced the size of fish retained, the precise relationships between mesh size and the size of fish caught had to be described by experiments at sea (ICNAF 1963, Holden 1971). It was found that many aspects of trawl construction affected this relationship, particularly netting material (the different types of natural and synthetic fibres) and gear construction, particularly chafing gears (materials attached to codends to reduce damage to netting) (McCracken 1960). The growth and mortality of each of the fish stocks had also to be described, as well as the size and age composition of catches, so that the changes in yield to be expected from increasing mesh size could be worked out using yield-per-recruit models. While the first regulation of mesh size came into effect in 1953, there were many causes for uncertainty about whether increasing mesh size would in actuality improve yields. However, it seemed likely to be beneficial if for no other reason than that the efficiency of fishing operations would be increased from not having to throw large quantities of fish over the side (Graham 1952). It was not until 1961 that ICNAF's scientific committee was able to give a definitive statement on the expected benefits from mesh regulation in the groundfish fisheries (Beverton \& Hodder 1962) and 1968 before the full extent of the research was reflected in regulations.

By the 1960s, it was becoming increasingly clear to ICNAF that action on the central tenet of the theory of fishing, control of the amount of fishing 
effort, was essential. There were two ways to control the amount of fishing effort, either directly by limiting the time vessels spent fishing or by limiting the amounts of fish caught. The scientific problems involved in applying one or the other of these methods were quite different. Direct control of fishing effort required inter-calibrating the many different vessel and gear types in use in terms of the mortality they generated per unit of fishing activity and keeping track of changes in technology and fishing behaviour that might affect the ability of a fishing unit to generate fish mortality. Control of catch required prediction of the catch in the next fishing year that would cause the desired level of fishing mortality. This necessitated that the absolute size of the fish stock be estimated. The issue was very largely settled by ICNAF deciding that catch limits were the simpler solution from a multinational political/administrative perspective. Collapse of the haddock stocks in the late 1960s caused ICNAF to set TAC limits for them in 1970 and by 1974 all of the major directed fisheries in the Northwest Atlantic were under TAC regulation. Nonetheless, there were subsequent attempts to introduce direct fishing effort control. Thorough investigation by USA scientists in the early 1970s supported regulatory proposals for effort limitation for Subarea 5 (Fig 3 ) and adjacent waters to the south, to be implemented in addition to catch limitation. However, the USA proposals were technically too complex to obtain acceptance within ICNAF. A much simpler proposal was subsequently devised by Canadian scientists for Subareas 2-4 and was implemented for 1976, but the initiative was not sustained after Canada's extension of jurisdiction.

New scientific methods were developed that allowed the absolute size of fish stocks to be calculated and next year's catch to be projected, in support of TAC regulation. These methods are categorized as Sequential Population Analyses (SPA), original versions being called Virtual Population Analysis (Gulland 1965) and Cohort Analysis (Pope 1972). These methods require knowledge of commercial catches in number by age group for at least several previous years, and fishing mortality in the most recent year. Estimating catches by age group requires accurate estimates of total catch tonnages by stock area and biological samples from the catches of each country by gear type and season, because age composition varies by these factors. Estimates of total mortality could be obtained from the changes in catch rates of commercial vessels from one year to the next for specific year-classes or cohorts. Fishing mortality could then be calculated by subtracting natural mortality from this total mortality estimate. Natural mortality was not well estimated but appeared to be low compared to fishing mortality and results were not expected to be greatly affected by this uncertainty (an assumption that came to be regretted in later years - see below).

Initial concerns in application of the SPA and catch projection method to Northwest Atlantic stocks were related to lack or incompleteness of data. While Canadian port sampling and fishery statistics programs had been in place for some years, various other countries were ill-equipped to meet the data collection requirements for TAC regulation. Biological sampling of 
catches was particularly problematic for countries whose vessels processed catches at sea. Obtaining estimates of quantities discarded at sea proved to be an intractable problem (although not for freezer trawlers, which processed virtually everything). Another difficulty in projection was accounting for the strength of new year-classes entering the fishery during the projection period and it was necessary to assume that future recruitment would be similar to that observed in the past. This was an important issue for short-lived species, such as silver hake, for which recruiting year-classes formed an important part of the projected catch.

Initially, time series of commercial catch rates were depended upon to calibrate, or 'tune', SPA estimates of present stock size, but many factors could cause changes in catch rates other than population abundance and it was anticipated that the imposition of catch (or effort) controls would make this approach even less reliable. Scientists from the USA had initiated a series of standardized research vessel bottom trawl surveys off New England in 1963 that provided fishery-independent estimates of stock abundance. As small mesh nets were used, these also provided estimates of the strength of recruiting year classes. Such surveys offered a solution to the issues of SPA tuning and catch forecasting and, at the beginning of the 1970s, ICNAF adopted a program to extend their geographic scope to the entire Northwest Atlantic, a goal achieved by the end of the decade (Doubleday \& Rivard 1981, Doubleday 1981). These surveys initially supplemented and gradually supplanted commercial catch rates for calibrating SPAs. In addition, the initial subjective approaches to calibration were replaced by more statistically rigorous methods for calculating commercial catch rates (Gavaris 1980) and for SPA calibration (Gavaris 1988) and methods of estimating the uncertainty of model projections were developed (Smith et al. 1993). Deficiencies in data on foreign commercial fisheries were addressed by establishment in 1979 of an International Observer Program that put Canadian observers aboard foreign boats fishing in the Canadian zone to collect biological data on catches and information for enforcement purposes. This program was subsequently extended to the domestic fleet.

While maintaining and improving the short-term projection procedure in support of the TAC management system became a major element of the science program for finfish management from the early 1970s, other research was not completely ignored. It was thought that the primary deficiency of the yield per recruit methodology being used to provide advice was that it did not take into account the factors affecting recruitment, which was the primary determinant of fish stock production. There were two main approaches to this problem, the first being to relate parent stock size with subsequent recruitment by fitting mathematical models to data from the fisheries (see below) and the second to conduct field experiments to determine the mechanisms involved in determining year-class success. In the Northwest Atlantic, the first large scale field program to try to link recruitment to parent stock or environmental effects was conducted in 1965-74 for cod in the southern Gulf of St. Lawrence (Lett et al. 1975). This was 
followed in the late 1970 s by similar multi-national studies, sponsored by ICNAF/NAFO, on Georges Bank herring (Grosslein 1987) and Flemish Cap cod and redfish (Lilly 1987). Canadian scientists participated extensively in these initiatives. On the Scotian Shelf, where almost nothing was known about the spatial and temporal distribution of fish eggs and larvae, a series of broad-scale surveys were conducted in 1977-82 (the Scotian Shelf Ichthyoplankton Program) (O'Boyle et al. 1984, Sinclair 1988). This served, in part, as a basis for a Fisheries Ecology Program that conducted field sampling off southwest Nova Scotia in 1983-85 (Smith et al. 1989). Although these very expensive field programs generated a great deal of valuable information about the species and areas studied, they unfortunately contributed little to understanding the causes of recruitment variability. By the mid 1980s, budgets for fisheries science were being reduced and program scope had narrowed, essentially, to research directly in support of stock assessment.

Gear research and development, and exploratory fishing for species not utilized by the Canadian industry, continued to be of importance within the science program in the 1960s. Subsequently, these activities became insignificant within science programs, but they were continued within 'industrial development' branches established within the operations side of the organization. Increasingly, in the 1980s and subsequently, development-type research was directed to conservation-related issues such as reducing bycatches and the catches of small fish, e.g. by demonstrating the benefits of using square mesh netting (Halliday et al. 1999) and sorting grids in trawl nets (Halliday \& Cooper 1999).

\section{0 to Present}

As already mentioned, ICNAF's objective was to obtain MSY, equated to $\mathrm{F}_{\text {max }}$, but Canada adopted a strategy of fishing at $\mathrm{F}_{0.1}$, the most conservative strategy among those adopted by national and international management agencies throughout the North Atlantic (Halliday \& Pinhorn 1996). Nonetheless, it was the groundfish stocks in the Canadian zone that collapsed catastrophically in the early 1990s. Although frequently portrayed as the collapse of the cod stocks, other stocks of both commercial and non-commercial groundfish species also collapsed, particularly in the northern part of the zone. While the history of the fisheries is one of lurching from one crisis to another, this collapse was in a class of its own and created great economic and social hardship, particularly in Newfoundland.

This collapse of the groundfish stocks was not foreseen by the scientific community and created a crisis of confidence in CAFSAC, its scientific advisory body. The degree of dissatisfaction with scientific advice was reflected, for example, by the Minister taking the responsibility for providing advice on groundfish management from his departmental scientists and placing it in the hands of an outside body, the FRCC (see above under Fisheries Management). 
Explanations put forward for the early 1990s groundfish collapse were overfishing, a large-scale environmental change or some combination of these factors. The primary debate centred on the large cod stock off Labrador and eastern Newfoundland, the 'Northern cod'. The initial interpretation of its collapse was that there had been a sudden, substantial increase in natural mortality due to ecosystem changes (Lear \& Parsons 1993, Atkinson \& Bennett 1994). However, this was soon refuted in analyses that attributed the decline to fishing mortality alone (Hutchings \& Myers 1994, Hutchings 1996). Public opinion (including fishermen's organizations and many academic and applied fisheries scientists) was overwhelmingly in favour of a view that over-fishing and overfishing alone was the cause of the collapse. CAFSAC advice that gave credence to other explanations was characterized as evidence of bureaucratic interference in the advisory process (Hutchings et al. 1997a). (See also rebuttal by Doubleday et al. (1997) and reply by Hutchings et al. (1997b).) The Northern cod collapse came to be viewed internationally as a prime example of the disastrous effects of overfishing.

How could this have happened in such a highly regulated and monitored regime? Scientists had become aware in the mid 1980s that the new statistical methods for tuning SPAs were prone to biases in estimates of current stock size, likely due to data deficiencies (Sinclair et al. 1985, 1990). Initial estimates retrospectively proved most often to be too high, causing TACs to be set too high in relation to the $F_{0.1}$ reference point. This 'retrospective problem' clearly contributed to exploitation rate being higher than intended, a problem compounded by deficiencies in the control of fishing, see e.g. Angel et al. (1994). Nonetheless, one of the reasons $F_{0.1}$ was chosen as a reference point was to make allowance for just such deficiencies. The Fs estimated for Canadian cod stocks in the 1980s were a bit above $F_{\text {max }}$, the lowest for cod in any of the North Atlantic management regimes in that period (Halliday \& Pinhorn 1996). Arguments can be made that these $F$ estimates are unreliable, but if they are given credence, it seems unlikely that high $\mathrm{F}$ was the cause of the collapse of Canadian stocks while those elsewhere did not suffer a similar failure.

There is scope for an argument that the large scale overfishing occurred not during the 1980s but over a brief period in the early 1990s. For example, unreported catches were seen by Shelton \& Lilly (2000) as the most plausible explanation for the collapse of the Northern cod. Nonetheless, they found it disconcerting that their estimate of the amount of fish missing from the statistical record was larger than the combined catching capacity of the Canadian and foreign fleets, and thus were forced to recognize that other factors were also involved.

In keeping with the view that the groundfish stock collapses were primarily, or perhaps entirely, due to fishing, the limitations of yield-per-recruit methods came to the fore in stock assessment evaluations and, in particular, the fact that they did not take into account the effect of spawning stock size on recruitment. Some scientists thought that if stock assessments had 
included reference points for minimum spawning stock sizes the collapses might have been avoided. The large-scale field studies in the late 1970s - early 1980s had not been successful in determining the causes of recruitment variability (see above), leaving the modelling of relationships between parent stock and subsequent recruitment from fisheries-related data as the only avenue of pursuit. Unfortunately, the variability in observational data for teleost fishes makes a statistical relationship between spawning stock and subsequent recruitment essentially impossible to discern, requiring that the form of the relationship be assumed. Making assumptions about the form of stock-recruitment relationships was tolerated for exploratory scientific modelling, but to actually use such assumptions as a basis for management advice was long seen as unjustifiable. However, the United Nations agreement relating to the conservation and management of straddling fish stocks and highly migratory fish stocks in 1995 (United Nations 1995), which resurrected MSY as the foundation for reference points for application of the precautionary approach, gave licence to ignore these longstanding reservations. Much effort in recent years has been put into defining reference points for spawning stock biomass as central elements of decision rules for setting allowable catches for each stock.

An alternative school of thought developed in the late 1990s that rejected yet more complex theory-based modelling of single stocks as the basis for scientific advice. These scientists thought that having the key reference points on which fisheries would be opened and closed based on no more than assumptions was not a reliable basis for management and that this approach gave false assurances to fisheries managers and the fishing industry about sustainability. They proposed data-based alternatives that depended more heavily on biological knowledge. The Traffic Light Method (Caddy 1999) was one such alternative that received considerable scientific attention (Halliday et al. 2001). This method establishes a precautionary decision framework based on a multiplicity of indicators based on biological, fishery and environmental data (and can include the outputs from complex assessment models). The Traffic Light approach has been applied in some cases where there were insufficient data to allow the use of mathematical modelling, such as assessments for shrimp (Koeller et al. 2000) and crab (Caddy et al. 2005), but has not yet been accepted as a preferred alternative to reliance on traditional methods.

The groundfish stock collapses also caused a renewal of research interest within the fisheries science community in biological and ecological questions, rather than simply single species stock dynamics. Studies illustrated that the late 1980s - early 1990s decrease in groundfish populations were broadly coincidental with large changes in all elements of the ecosystem, physical oceanography, phytoplankton, zooplankton, pelagic fishes and benthic invertebrates (e.g. Frank et al. 2006, DFO 2003). Causes of the many changes observed in the biological characteristics of groundfish stocks prior to and during their collapse were studied and the assumptions underlying assessment models were re-examined. Of particular note in 
this latter regard was the discovery that natural mortality of cod had been much higher than previously thought in southern Gulf of St. Lawrence cod (Sinclair 2001). This insight was based on estimates of total mortality from research vessel surveys, which could be attributed to natural mortality, fishing mortality being negligible due to fishery closures. (A new method of estimating natural mortality from SPA (Chouinard et al. 2005) has since confirmed Sinclair's results.) Applying Sinclair's method to other stocks showed that natural mortality in the early 1990s for at least some cod stocks was likely sufficiently high to alone account for their collapse. Laboratory and field investigations of causes for this increase in natural mortality illustrated that a reduction in fish condition (the ratio of weight to length) was a prime candidate (Dutil \& Lambert 2000). It can be hypothesized that oceanographic changes caused large-scale distributional shifts (Rose et al. 1994, Kulka et al. 1995, Castonguay et al. 1999) that resulted in reduced food availability, a consequent decline in condition and elevated over-wintering and post-spawning mortality. Predation on cod by expanding seal populations was examined as another possible contributory factor for higher cod mortality. While deemed not to have been a major factor in the initial collapse, seal predation could be an impediment to stock recoveries (Mohn \& Bowen 1996, Fu et al 2001, Chouinard et al. 2005). These observations provide support for a strong environmental contribution to the 1990s ecosystem disruptions.

Increasingly, scientists have found it necessary to admit that overfishing was not the sole cause of the early 1990s groundfish stock collapses, but the conventionally accepted explanation remains that fishing was, nonetheless, the primary causative factor, see e.g. Rice (2002). It may never be possible to give a definitive answer to the respective roles of fishing and the environment in this event. However, it seems likely that the key role of environmental change in causing the collapses will come to be more fully appreciated.

\section{DISCUSSION}

Fisheries science has benefited from its beginnings in the early $20^{\text {th }}$ century from rapid exchange of ideas and strong international cooperation fostered through science and management institutions such as ICES and the fisheries commissions. The science for Canadian Atlantic coast fisheries did not differ greatly from that for fisheries off Europe and elsewhere. The ICNAF initiative to institute a Northwest Atlantic standardized bottom-trawl survey program using research vessels proved foresighted and was adopted elsewhere. These surveys have provided a platform for broad-scale ecosystem monitoring, the importance of which became increasingly well recognized after fishery closures, and as management of uses of the ocean generally became a focus of interest with passage of Canada's Oceans Act in 1997. The Canadian introduction of observers on most foreign vessels fishing in its zone from 1979, and subsequently on domestic vessels, was also unique 
among North Atlantic management regimes in its scale of application. It provided data valuable for research when coverage approached $100 \%$ but its dual role of enforcement and scientific data collection compromised its usefulness to scientists in other cases.

There was also commonality in regulatory approaches by North Atlantic management authorities. Although ICNAF was the first to embark upon catch controls, as a political imperative in the face of rapidly increasing international fishing effort and collapsing fisheries, it was immediately followed by the North-East Atlantic Fisheries Commission. Domestic fisheries jurisdictions in general maintained continuity with the practices of the international commissions at the time of their jurisdictional extensions; Canada was not exceptional in this regard.

The science community was ill-equipped to support the international commissions' TAC initiatives. New scientific methods were rapidly developed and immediately applied, using data that suffered from many inadequacies, and there was no scope for evaluating the accuracy of the advice given in the relatively short time before the establishment of national jurisdictions. In Canada's case, the coincidence of groundfish stock recovery with extension of jurisdiction encouraged a view that the TAC system was indeed working, and that a large investment in a short-term catch forecasting service, as the basis for optimal exploitation ("best use") of the resources, was worthwhile.

In retrospect, there are reasons to question whether this singular preoccupation with accurate catch forecasting was the best use of scientific resources. The uncertainty in scientific advice remains high, despite 30 years of continuous development of methods, and is unlikely to improve due to the variability inherent to fisheries and survey data (see, e.g. National Research Council (US) (1998)). The reliability of catch projections is too low to make annual adjustments in TACs to maintain fishing mortality rates at $\mathrm{F}_{0.1}$, or some other reference point, a practical endeavour. (Nor is the regulatory system capable of controlling catches with a level of precision compatible with optimal exploitation - which contributes to assessment uncertainties.) More general scientific guidance for management would be less costly and more useful for being less likely to mislead.

The wisdom of the decisions being made in scientific advisory bodies to implement the precautionary approach using model-based limit reference points for spawning stock sizes is also open to question. The methodology utilizes stock assessment output data and introduces more assumptions to those that already underlie the assessment. An application of the precautionary approach, to be consistent with Annex II of the 1995 UN Fisheries Agreement (United Nations 1995), requires that these limit reference points trigger pre-agreed conservation and management actions, such as the opening and closing of a fishery. Decisions of such economic and social importance should be based on sounder footings. Schnute \& Richards (2001) provide an invaluable perspective on the use and abuse of fishery models in the provision of scientific advice and warn against the practice 
of depending on the output from single models. Caddy (2002) has noted that the precautionary approach issue has provided scientists with much scope for career enhancement through production of scientific papers, but that the focus on resolving scientific issues about indicators has diverted attention away from involving the industry and managers in developing frameworks for taking action. Decision frameworks using readily available, data-based indicators that fishermen and managers can understand, are the ones likely to obtain the support of industry and thus have some positive practical effect.

Most importantly perhaps, a singular focus on description of the dynamics of individual stocks and the effects of fishing axiomatically precludes recognition of excluded factors that may have equal or greater effects on stock abundance. This is simply a repetition of a long-standing criticism of single-species stock assessment. However, the controversy over the causes of the early 1990 s collapse of the groundfish fisheries emphasises the need for a return to a broader-based fisheries science that puts fish stocks in the context of their ecosystem. This requires research through field data collection and laboratory experimentation to provide knowledge of cause and effect, and the use of mathematical models as research tools for evaluating hypotheses.

Appropriate institutional arrangements are the key to success in fishery management, as in all such endeavours. The regionalization of fisheries science in the mid-1970s fractionated science, but did not effectively integrate science and operations within regional management organizations. Successful implementation of fisheries policies and plans requires adoption of an operations research, now known as a management science, approach to policy implementation (Lane \& Stephenson 1999). New institutional arrangements that put an operational research function in the middle between traditional science and operations units, analogous to much earlier proposals, e.g. in a Canadian context by Regier \& McCracken (1975) and generally by Edwards (1981), offer a constructive way forward.

Acknowledgements. We thank R. O'Boyle and W. Stobo, Science Branch, DFO, Maritimes Region, for their constructive criticisms of an earlier draft.

\section{REFERENCES}

Anderson ED (1998) The history of fisheries management and scientific advice - the ICNAF/NAFO history from the end of World War II to the present. J Northw Atl Fish Sci 23:75-94

Angel JR, Burke DL, O'Boyle RN, Peacock FG, Sinclair M, Zwanenburg KCT (1994) Report of the Workshop on Scotia-Fundy Groundfish Management from 1977 to 1993. Can Tech Rep Fish Aquat Sci 1979

Atkinson DB, Bennett BE (1994) Proceedings of a northern cod workshop held in St. John's, Newfoundland, Canada, January 27-29, 1993. Can Tech Rep Fish Aquat Sci 1999 
Beverton RJH, Hodder VM (1962) Report of Working Group of Scientists on Fishery Assessment in Relation to Regulation Problems. ICNAF Annual Proceedings, 11 (Supplement)

Beverton RJH, Holt SJ (1957) On the dynamics of exploited fish populations. Min Agr Fish Food UK, Fish Invest Ser II, 19

Caddy JF (1999) Deciding on precautionary management measures for a stock based on a suite of limit reference points (LRPs) as a basis for a multi-LRP harvest law. NAFO Sci Coun Studies 32:55-68

Caddy JF (2002) Limit reference points, traffic lights, and holistic approaches to fisheries management with minimal stock assessment input. Fish Res 56:133137

Caddy JF, Wade E, Surette T, Hebert M, Moriyasu M (2005) Using an empirical traffic light procedure for monitoring and forecasting in the Gulf of St. Lawrence fishery for the snow crab, Chionoecetes opilio. Fish Res 76:123-145

Castonguay M, Rollet C, Fréchet A, Gagnon P, Gilbert D, Bręthes J-C (1999) Distribution changes of Atlantic cod (Gadus morhua L.) in the northern Gulf of St. Lawrence in relation to an oceanic cooling. ICES J mar Sci 56:333-344

Chouinard GA, Swain DP, Hammill MO, Poirier GA (2005) Covariation between grey seal (Halichoerus grypus) abundance and natural mortality of cod (Gadus morhua) in the southern Gulf of St. Lawrence. Can J Fish Aquat Sci 62:19912000

Copes $\mathbf{P}$ (1986) A critical review of the individual quota as a device in fisheries management. Land Economics 62:278-291

Copes P (1997) Social impacts of fisheries management regimes based on individual quotas. In: Palsson G, Petursdottir G (eds) Social implications of quota systems in fisheries. Nordic Council of Ministers, TemaNord 593:61-90

DFO (Department of Fisheries and Oceans) (2003) State of the Eastern Scotian Shelf ecosystem. DFO Ecosystem Status Report, 2003/004

DFO (2004)A policy framework for the management of fisheries on Canada's Atlantic coast. Misc Publ, Department of Fisheries and Oceans, Ottawa, ON

DOE (Department of Environment) (1976) Policy for Canada's commercial fisheries. Department of Environment, Ottawa, ON

Doubleday WG (1981) Manual on Groundfish Surveys in the Northwest Atlantic. NAFO Sci Coun Studies 2:7-55

Doubleday WG, Atkinson DB, Baird J (1997) Comment: scientific inquiry and fish stock assessment in the Canadian Department of Fisheries and Oceans. Can J Fish Aquat Sci 54:1422-1426

Doubleday WG, Rivard D (eds) (1981) Bottom trawl surveys. Can Spec Publ Fish Aquat Sci 58

Dutil J-D, Lambert Y (2000) Natural mortality from poor condition in Atlantic cod (Gadus morhua). Can J Fish Aquat Sci 57:826-836

Edwards RL (1981) The excluded middle - or the need for a new paradigm. Fisheries 6(4):12-16

FAO (United Nations Food and Agriculture Organization) (1995) Code of conduct for responsible fisheries. FAO, Rome

Frank KT, Choi JS, Petrie B (2006) Marine ecosystem assessment: past, present, and future attempts. Proc NS Inst Sci 43:185-198

Fu C, Mohn R, Fanning LP (2001) Why the Atlantic cod (Gadus morhua) stock off eastern Nova Scotia has not recovered. Can J Fish Aquat Sci 58:1613-1623

Gavaris S (1980) Use of a multiplicative model to estimate catch rate and effort from commercial data. Can J Fish Aquat Sci 37:2272-2275 
Gavaris S (1988) An adaptive framework for the estimation of population size. Canadian Atlantic Fisheries Scientific Advisory Committee (CAFSAC) Research Document, 1988/29

Gordon HS (1954) The economic theory of a common-property resource: the fishery. J Polit Econ 62:124-142

Gough J (1991) Fisheries management in Canada 1880-1910. Can Manuscr Rep Fish Aquat Sci 2105

Gough J (1993) A historical sketch of fisheries management in Canada. Can Bull Fish Aquat Sci 226:5-53

Graham HW (1952) Mesh regulation to increase the yield of the Georges Bank haddock fishery. ICNAF Second Annual Report for the year 1951-52, 2:23-33

Graham M (1935) Modern theory of exploiting a fishery, and application to North Sea trawling. J Cons perm int Explor Mer 10:264-274

Grosslein MD (1987) Synopsis of knowledge of the recruitment process for Atlantic herring (Clupea harengus), with special reference to Georges Bank. NAFO Sci Coun Studies 11:91-108

Gulland JA (1965) Estimation of mortality rates. Annex to Rep Arctic Fish Working Group, ICES CM 3

Gulland JA (1968) The concept of the maximum sustainable yield and fishery management. FAO Fisheries Technical Paper, No. 70 FRs/T70 Fishery Management

Gulland JA, Boerema LK (1973) Scientific advice on catch levels. Fish Bull 71:325-335

Halliday RG, Cooper CG (1999) Evaluation of separator grates for reduction of bycatch in the silver hake (Merluccius bilinearis) otter trawl fishery off Nova Scotia, Canada. Fish Res 40:237-249

Halliday RG, Cooper CG, Fanning P, Hickey WM, Gagnon P (1999) Size selection of Atlantic cod, haddock and pollock (saithe) by otter trawls with square and diamond mesh codends of 130-155mm mesh size. Fish Res 41:255-271

Halliday RG, Fanning LP, Mohn RK (2001) Use of the traffic light method in fishery management planning. Canadian ScienceAdvisory Secretariat (CSAS) Research Document, 2001/108

Halliday RG, Peacock FG, Burke DL (1992) Development of management measures for the groundfish fishery in Atlantic Canada: a case study of the Nova Scotia inshore fleet. Mar Pol 16:411-426

Halliday RG, Pinhorn AT (1996) North Atlantic fishery management systems: a comparison of management methods and resource trends. J Northw Atl Fish Sci 20

Hart JL (1958) Biological Station, St. Andrews, N.B. 1908-1958: Fifty years of research in aquatic biology. J Fish Res Bd Canada 15:1127-1161

Holden MJ (ed) (1971) Report of the ICES/ICNAF working groups on selectivity analysis. Int Coun Explor Sea, Coop Res Rep Ser A, 25

Hutchings JA (1996) Spatial and temporal variation in the density of northern cod and a review of hypotheses for the stock's collapse. Can J Fish Aquat Sci 53:943-962

Hutchings JA, Walters C, Haedrich RL (1997a) Is scientific inquiry incompatible with government information control? Can J Fish Aquat Sci 54:1198-1210

Hutchings JA, Haedrich RL, Walters C (1997b) Reply: scientific inquiry and fish stock assessment in the Canadian Department of Fisheries and Oceans and reply: the interplay of policy, politics, and science. Can J Fish Aquat Sci 54:1430-1431 
Hutchings JA, Myers RA (1994) What can be learned from the collapse of a renewable resource? Atlantic cod, Gadus morhua, of Newfoundland and Labrador. Can J Fish Aquat Sci 51:2126-2146

ICNAF (International Commission for the Northwest Atlantic Fisheries) (1963) The selectivity of fishing gear. ICNAF Special Publication 5

ICNAF (1974) Report of the Third Special Commission Meeting, Ottawa, Canada, 15-19 October 1973. ICNAF Annual Report for the year 1973/74, 24:17-33

ICNAF (1976) Report of the Eighth Special Meeting of the International Commission for the Northwest Atlantic Fisheries, FAO, Rome, Italy, 21-26 January 1976. ICNAF Annual Report for the year 1975/76, 26:49-75

Johnstone K (1977) The aquatic explorers: a history of the Fisheries Research Board of Canada. University of Toronto Press, Toronto, ON

Kirby MJLC (1983) Navigating troubled waters - a new policy for the Atlantic fisheries. Report of the Task Force on Atlantic Fisheries. Department of Supply and Services, Ottawa, ON

Koeller PA, Savard L, Parsons DG, Fu C (2000) Precautionary approach to assessment and management of shrimp stocks in the Northwest Atlantic. J Northw Atl Fish Sci 27:235-246

Kulka DW, Wroblewski JS, Narayanan S (1995) Recent changes in the winter distribution and movements of northern Atlantic cod (Gadus morhua Linnaeus, 1758) on the Newfoundland-Labrador shelf. ICES J mar Sci 52:889-902

Lane DE, Stephenson RL (1999) Fisheries-management science: a framework for the implementation of fisheries-management systems. ICES J mar Sci 56:1059-1066

Larkin PA (1977) An epitaph for the concept of maximum sustained yield. Trans Am Fish Soc 106:1-11

Lear WH (1998) History of fisheries in the Northwest Atlantic: the 500-year perspective. J Northw Atl Fish Sci 23:41-73

Lear WH, Parsons LS (1993) History and management of the fishery for Northern cod in NAFO divisions 2J, 3K and 3L. Can Bull Fish Aquat Sci 226:55-89

Lett PF, Kohler AC, Fitzgerald DN (1975) Role of stock biomass and temperature in recruitment of southern Gulf of St. Lawrence Atlantic cod, Gadus morhua. J Fish Res Bd Canada 32:1613-1628

Lilly GR (1987) Synopsis of research related to recruitment of Atlantic cod (Gadus morhua) and Atlantic redfishes (Sebastes sp.) on Flemish Cap. NAFO Sci Coun Studies 11:109-122

McCracken FD (1960) Selectivity of codends with various types of topside chafers. ICNAF Redbook, Part II:66-69

Mohn R, Bowen WD (1996) Grey seal predation on the eastern Scotian Shelf: modelling the impact on Atlantic cod. Can J Fish Aquat Sci 53:2722-2738

NACFI (NorthAmerican Council on Fishery Investigations) (1932) Proceedings, 19211930, No 1. North American Council on Fishery Investigations, Ottawa, ON

National Research Council (US) (1998) Improving fish stock assessments. National Academy Press, Washington, DC

Needler AWH (1930) The migrations of haddock and the interrelationships of haddock populations in North American waters. Contr Canad Biol Fish, NS, Vol VI:243-313

Needler AWH (1950) Report for 1950 of the Atlantic Biological Station, St. Andrews, NB. In: Annual Report, 1950. Atlantic Biological Station, St Andrews, NB 
Needler AWH (1984) The seventy-fifth anniversary of two Canadian biological stations. Can J Fish Aquat Sci 41:216-224

O'Boyle RN (1985) A description of the two-tier catch quota system of ICNAF, with commentary on its potential usefulness in current fisheries management on the Scotian Shelf. Can Tech Rept Fish Aquat Sci 1347:196-200

O'Boyle RN, Sinclair M, Conover RJ, Mann KH, Kohler AC (1984) Temporal and spatial distribution of ichthyoplankton communities of the Scotian Shelf in relation to biological, hydrological, and physiographic features. Rapp P-v Reun Cons int Explor Mer 183:27-40

Parsons LS (1993a) Management of marine fisheries in Canada. National Research Council of Canada, Ottawa, ON

Parsons LS (1993b) Shaping fisheries policy: The Kirby and Pearse inquiries process, prescription and impact. Can Bull Fish Aquat Sci 226:385-409

Pope JG (1972) An investigation of the accuracy of virtual population analysis using cohort analysis. ICNAF Res Bull 9:65-74

Regier HA, McCracken FD (1975) Science for Canada's shelf-seas fisheries. Fisheries Research Board of Canada Background Study No. 1, Misc Publ, Environment Canada, Ottawa, ON

Rice J (2002) Changes to the large marine ecosystem of the Newfoundland-Labrador Shelf. In: Sherman K, Skjoldal HR (eds) Large marine ecosystems of the North Atlantic. Elsevier Science BV, Amsterdam, The Netherlands, p51-103

Rose GA, Atkinson BA, Baird J, Bishop CA, Kulka DW (1994) Changes in distribution of Atlantic cod and thermal variations in Newfoundland waters, 1980-1992. ICES mar Sci Symp 198:452-552

Schnute JT, Richards LJ (2001) Use and abuse of fishery models. Can J Fish Aquat Sci 58:10-17

Schrank WE (2005) The Newfoundland fishery: ten years after the moratorium. Mar Pol 29:407-420

Shelton PA, Lilly GR (2000) Interpreting the collapse of the northern cod stock from survey and catch data. Can J Fish Aquat Sci 57:2230-2239

Sinclair A, Gascon D, O'Boyle R, Rivard D, Gavaris S (1990) Consistency of some Northwest Atlantic groundfish stock assessments. NAFO SCR Doc 90/96, Ser No N1831

Sinclair AF (2001) Natural mortality of cod (Gadus morhua) in the southern Gulf of St Lawrence. ICES J mar Sci 58:1-10

Sinclair M (1988) Historical sketch on recruitment research. Can Tech Rep Fish Aquat Sci 1626:8-30

Sinclair M, Anthony VC, lles TD, O’Boyle RN (1985) Stock assessment problems in Atlantic herring (Clupea harengus) in the Northwest Atlantic. Can J Fish Aquat Sci 42:888-898

Smith PC, Frank KT, Mahon R(1989) General introduction to southwest Nova Scotia Fisheries Ecology Program (FEP): 1982-89. Can J Fish Aquat Sci 46:2-3

Smith SJ, Hunt JJ, Rivard D (eds) (1993) Risk evaluation and biological reference points for fisheries management. Can Spec Publ Fish Aquat Sci 120

Smith TD (1994) Scaling fisheries: The science of measuring the effects of fishing, 1855-1955. Cambridge University Press, Cambridge

Stewart JE, Safer A (2005)A retrospective: three quarters of a century at the Halifax Fisheries Research Laboratory. Proc NS Inst Sci 43:19-44

Thompson $\mathbf{H}$ (1939) The occurrence and biological features of haddock in the Newfoundland area. Research Bulletin 6, Newfoundland Department of Natural Resources, St. John's, NL 
Thompson H (1943) A biological and economic study of cod (Gadus callarias, L.) in the Newfoundland area including Labrador. Research Bulletin 14, Newfoundland Department of Natural Resources, St. John's, NL

United Nations (1995) Agreement for the implementation of the provisions of the United Nations Convention on the Law of the Sea of 10 December 1982 relating to the conservation and management of straddling fish stocks and highly migratory fish stocks. United Nations conference on straddling fish stocks and highly migratory fish stocks, sixth session. A/CONF 164/37

Went A (1972) Seventy years agrowing. Rapp Proc-Verb ICES 165 